\title{
Cold Hardiness of Evergreen Azaleas Is Increased by Water Stress Imposed at Three Dates
}

\author{
Tomasz Anisko and Orville M. Lindstrom \\ Department of Horticulture, University of Georgia, Georgia Experiment Station, Griffin, GA 30223 \\ Additional index words. cold acclimation, Rhododendron, water potential
}

\begin{abstract}
The effect of water stress imposed at three dates in late summer and early fall on cold hardiness was examined in Rhododendron L. 'Coral Bell', 'Hinodegiri', and 'Red Ruffle'. The persistence of the water stress-induced cold hardiness was also examined following plant recovery from the stress. Container-grown plants were exposed to three weeks of reduced water supply starting $8 \mathrm{Aug}$., $29 \mathrm{Aug}$., or $19 \mathrm{Sept}$., while control plants were well watered. Cold hardiness of leaves, lower, middle, and upper stems was evaluated with laboratory freeze tests. Reduced water supply independent of time initiated increased cold hardiness by 1 to $4 \mathrm{C}$ in the majority of the tested plant parts in the three cultivars. Cold hardiness of all plant parts tested strongly depended on the current water status of the plants as indicated by the stem water potential. In most cases, 3 weeks after rewatering, the cold hardiness of previously water stressed plants did not differ from that of nonstressed plants.
\end{abstract}

Seasonal changes in cold hardiness have been correlated to the water content of the plant tissue in several plants, including 'Hetzi' juniper (Pellett and White, 1969), jack pine (Calme et al., 1993), lodge-pole pine (Jonsson et al., 1981), black spruce (Colombo, 1990; Calme et al., 1993), white spruce (Calme et al., 1993), Koster azalea (Lindstrom et al., 1977), and red-osier dogwood (Chen et al., 1975; Li and Weiser, 1971; McKenzie et al., 1974; Parsons, 1978). Artificial dehydration of tissues has been demonstrated to increase cold hardiness in red-osier dogwood (Li and Weiser, 1971), rye (Siminovitch, 1977), winter wheat (Tyler et al., 1981), and cabbage (Cox and Levitt, 1976). In contrast, Takatoi et al. (1964) found that there was no relationship between cold hardiness and tissue water content in birch and alder trees.

Despite some previous research, the ability to modify cold hardiness by tissue water content through cultural practices is unclear. Water stress increased cold hardiness in several herbaceous plants including alfalfa (Paquin, 1977), winter wheat (Gusta et al., 1982; Cloutier and Siminovitch, 1982), and asparagus (Burrows et al., 1989). Cold hardiness of red-osier dogwood was increased from -3 to $-12 \mathrm{C}$ by reducing watering to suboptimal level for 3 weeks (Chen et al., 1975; Chen et al., 1977; Chen and $\mathrm{Li}, 1978$ ). Nelson et al. (1993) reported that withholding irrigation of jojoba for part of the growing season increased cold hardiness of flower buds. Acclimation of citrus trees induced by water stress or low temperature resulted in a similar level of cold hardiness (Yelenosky, 1979). Cold hardiness of evergreen azaleas was increased by growing them under a reduced water supply for 6 weeks in the fall (Anisko and Lindstrom, 1995). In contrast, van den Driessche (1969) reported that reducing the water supply had no direct effect on cold hardiness of Douglas-fir seedlings.

The effect of water stress on cold hardiness may depend on the timing of stress application. Blake et al. (1979) submitted Douglasfir seedlings to water stress for about 30 days at various times during the summer and observed an increase in cold hardiness only when stress treatment began before photoperiodic induction of dormancy (around 1 Aug.). Only actively growing Douglas-fir

Received for publication 19 June 1995. Accepted for publication 12 Oct. 1995. The authors sincerely thank Tom Dodd Nurseries of Semmes, Ala., and McCorkle Nurseries of Dearing, Ga., for providing plant material for this study. The cost of publishing this paper was defrayed in part by the payment of page charges. Under postal regulations, this paper therefore must be hereby marked advertisement solely to indicate this fact. seedlings increased in cold hardiness when exposed to water stress (Blake et al., 1979). Calme et al. (1993) found that cold hardiness of black spruce seedlings was not affected by water stress imposed by withholding irrigation for 2 weeks starting 13 Aug. They, similarly, attributed the lack of water stress-induced hardening to the timing of the stress application after initiation of dormancy.

Little is also known about changes in hardiness following recovery from water stress. Parsons and Li (1979) demonstrated that reduced watering during a 3-week period increased cold hardiness of red-osier dogwood by 8 to 10C. On rewatering, however, water stressed plants lost most of their induced hardiness in the next 3 weeks. Similarly, Amundson et al. (1993) withheld irrigation of red spruce trees from 18 Aug. to $13 \mathrm{Sept}$, and found cold hardiness of stressed trees to increase during and immediately after the water stress period. The water stress-induced hardiness was lost 3 weeks after resuming irrigation. Burrows et al. (1989) reported that rehydration of water stressed asparagus nullified previous increase in cold hardiness. In contrast, Stout (1980) found the increase in cold hardiness of alfalfa remained for several weeks after the water stress treatment. Timmis and Tanaka (1976), demonstrated that growing Douglas-fir seedlings for 8 or 9 weeks under reduced irrigation did not affect cold hardiness measured immediately following stress treatment. Cold hardiness measured 5 and 11 weeks after resuming normal irrigation was significantly increased in seedlings previously under water stress treatment. These studies indicate that the timing of water stress and changes in plant cold hardiness following recovery from the stress need to be considered in evaluating the effectiveness of water stress to induce plant cold hardiness. Some landscape plants, evergreen azaleas in particular, are prone to early freeze injury due to delayed acclimation. Measures to prevent freeze injury include promoting acclimation of azaleas by reducing water supply in late summer and early fall (Anisko and Lindstrom, 1995).

The purpose of this study was to examine the importance of water stress timing for an increase in cold hardiness in evergreen azaleas, and to examine the persistence of an increase following the recovery from stress.

\section{Materials and Methods}

Four-year-old plants of three evergreen azalea cultivars, Rhododendron 'Coral Bell' (CB), 'Hinodegiri' (HD), and 'Red Ruffle' (RR), were grown in 9-liter containers in an unheated plastic 

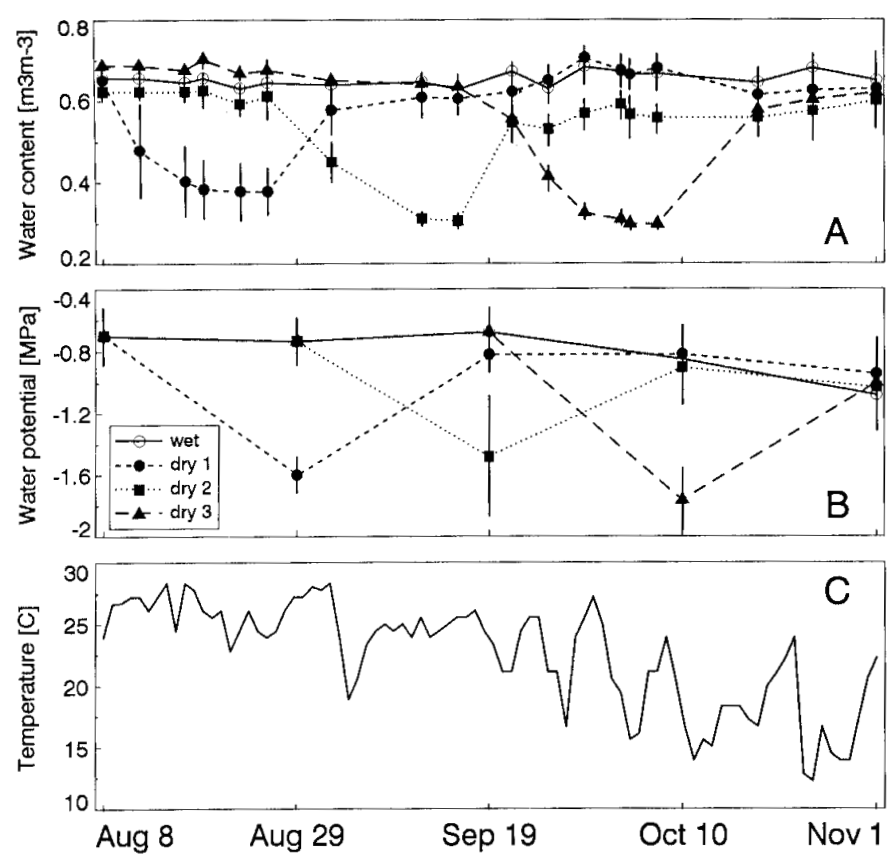

Fig. 1. Volumetric water content of the growing medium (A), stem water potential (B) of plants under four watering regimes, and mean air temperature (C) (vertical bars represent the standard deviation of the mean, $n=9$ ).

house. The growing medium (metro mix 300; Grace Sierra Horticultural, Milpitas, Calif.) contained Canadian sphagnum peat, vermiculite, processed bark ash, and washed sand. Plants were fertilized ( $1 \mathrm{~g} \cdot$ liter $\left.^{-1}\right)$ with Sta-green (11N-5P-5K; Progress Growers Supply, Canton, Ga.) three times between March and June. The study was located in Griffin, Ga., and plants were exposed to the natural daylength.

Plants were grown under four watering regimes (Fig. 1A). Water content of the growing medium for control plants was maintained near field capacity between 8 Aug. and 1 Nov. (wet). Water stressed plants were exposed to 3 weeks of reduced water supply starting 8 Aug. (dry 1), 29 Aug. (dry 2), or 19 Sept. (dry 3). Watering of the water stressed plants was delayed until volumetric water content was below $0.4 \mathrm{~m}^{3} \cdot \mathrm{m}^{-3}$. Watering then $\mathrm{r}^{\ldots \ldots} \cdots$ water content was maintained between 0.3 and 0.4 $\mathrm{m}^{3} \cdot \mathrm{m}^{-3}$. The volumetric water content of the growing medium was monitored with a time-domain reflectometry technique as described by Anisko et al. (1994). The method used a cable tester (Tektronix 1502C metallic time domain reflectometer; Tektronix, Beaverton, Ore.) to measure the apparent dielectric permittivity of the growing medium, which strongly depended on water content. An empirical relationship between dielectric constant and water content has been developed in a form of a calibration equation (Anisko et al., 1994). Plants were organized in three randomized complete blocks with three plants per block $\times$ cultivar $\times$ watering regime. A randomly selected pot in each block $\times$ cultivar $\times$

Fig. 2.The lethal temperature for lower, middle, and upper stems, and leaves of $R$. 'Coral Bell' plants subjected to four watering regimes (mean separation between the watering regimes within a freeze test date by Tukey's studentized range; data points with the same letters do not differ significantly at $P=0.05$ ). watering regime was used for monitoring volumetric water content. Water potential was measured with a pressure bomb (Soilmoisture Equipment, Santa Barbara, Calif.) on the upper stems with leaves attached. Measurements were performed in early morning (0800 HR) at the start of the treatments and on the four freeze test dates. One stem from a randomly selected plant representing each block $\times$ cultivar $\times$ watering regime was used for water potential measurements. Mean daily air temperature was calculated and based on the average of minimum and maximum temperature measured at the site of the experiment during the day from sunrise to sunrise.

Cold hardiness of plants was evaluated in the laboratory with freeze tolerance tests on leaves and stems as previously described (Anisko and Lindstrom, 1995). Stem sections were sampled from three locations on a plant: lower stems were the most basal stems up to $4 \mathrm{~cm}$ from the roots, upper stems were the current season's growth leafy stems, and middle stems were leafless stems of the intermediate position. The freeze tolerance tests were performed on 29 Aug., 19 Sept., 10 Oct., and 1 Nov.

\section{Results and Discussion}

Plants exposed to 3 weeks of reduced water supply experienced a degree of water stress indicated by the lower water potential measured on freeze test dates (Fig. 1B). When watering returned to control levels, the water potential of stressed plants fully recovered. The observed water potential in the water stressed plants $(-1.5$ to $-1.8 \mathrm{MPa})$ corresponded to the values obtained by Timmis and Tanaka (1976) in Douglas-fir (-1.2 MPa), Chen et al. (1977) in red-osier dogwood (-1.7 MPa), Burrows et al. (1989) in asparagus (-1.4 MPa), and Amundson et al. (1993) in red spruce $(-1.3$ to $-2.3 \mathrm{MPa})$.

Subjecting plants to 3 weeks of reduced water supply significantly increased cold hardiness regardless of timing compared to the control plants. The only exceptions were the middle stems of CB on 29 Aug. and the leaves of RR on 10 Oct. (Figs. 2-4). The increase in cold hardiness ranged in $\mathrm{CB}$ from 1.3C (middle stems on 29 Aug.) to $4.2 \mathrm{C}$ (lower stems on 19 Sept.), in HD from $1.8 \mathrm{C}$ (lower stems on 10 Oct.) to $3.7 \mathrm{C}$ (middle stems on 19 Sept.), and in RR from 0.5C (leaves on 10 Oct.) to 3.5C (leaves on 19 Sept.). Similar increases in cold hardiness were observed when the same

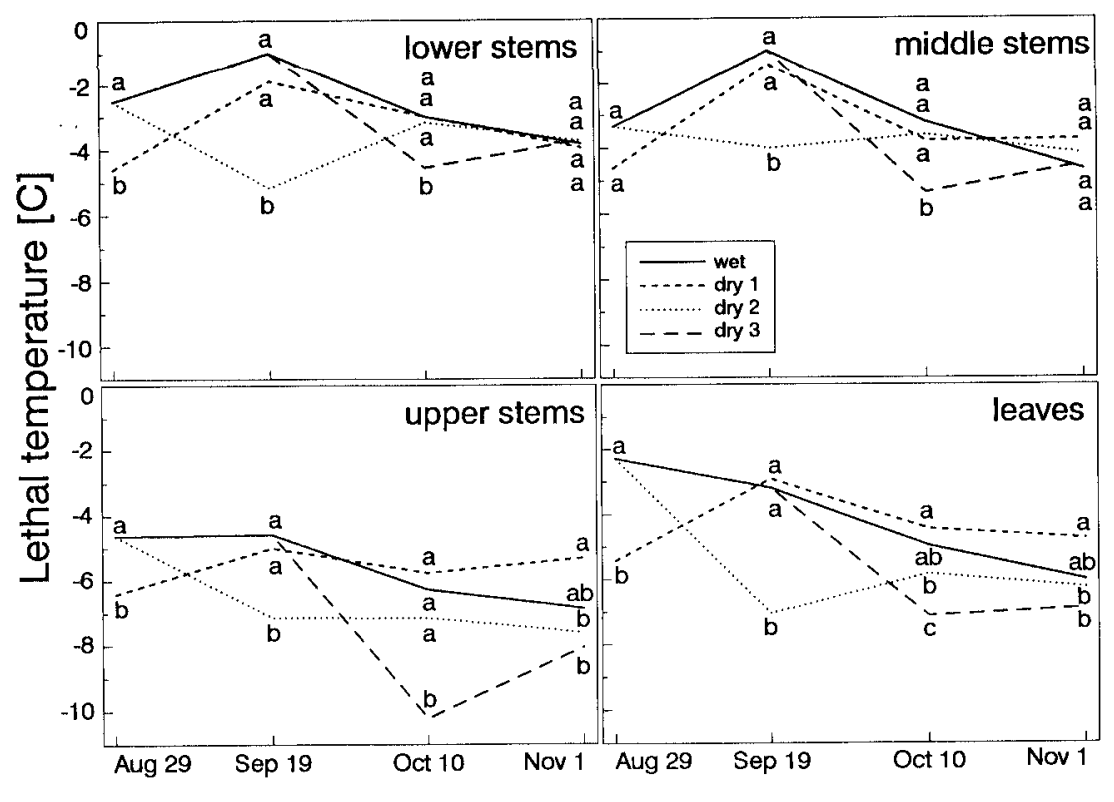




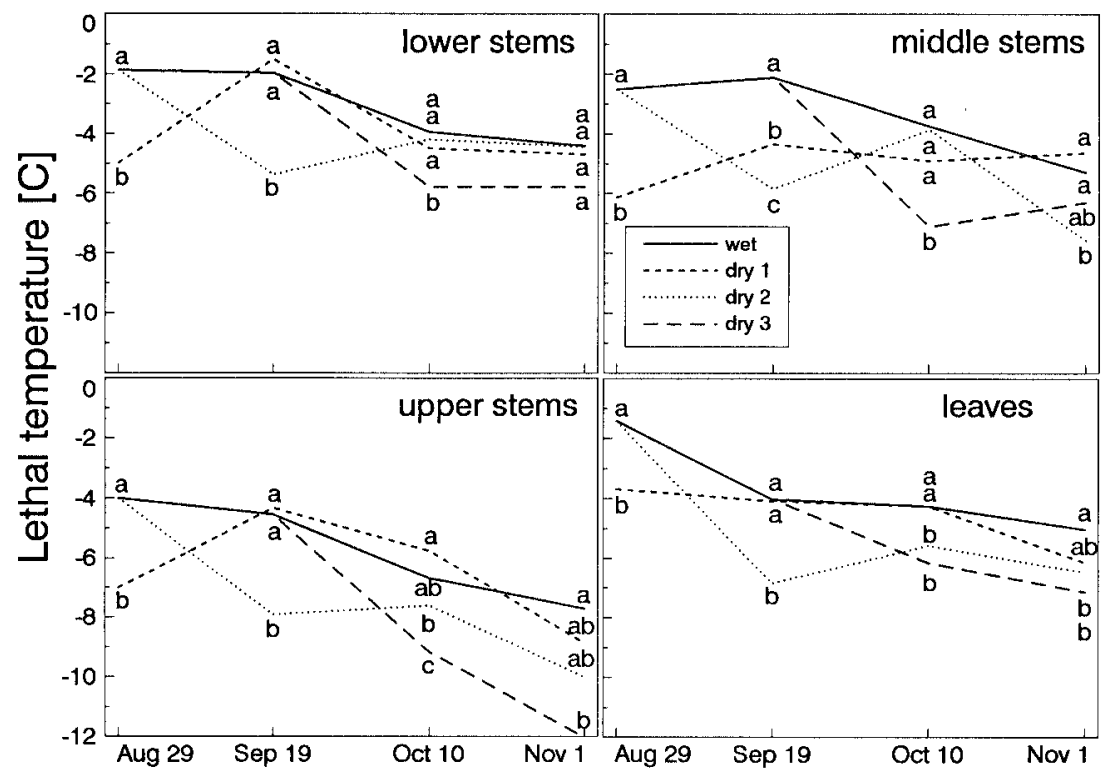

Fig. 3. The lethal temperature for lower, middle, and upper stems, and leaves of Rhododendron 'Hinodegiri' plants subjected to four watering regimes (mean separation between the watering regimes within a freeze test date by Tukey's studentized range; data points with the same letters do not differ significantly at $P=0.05$ ).

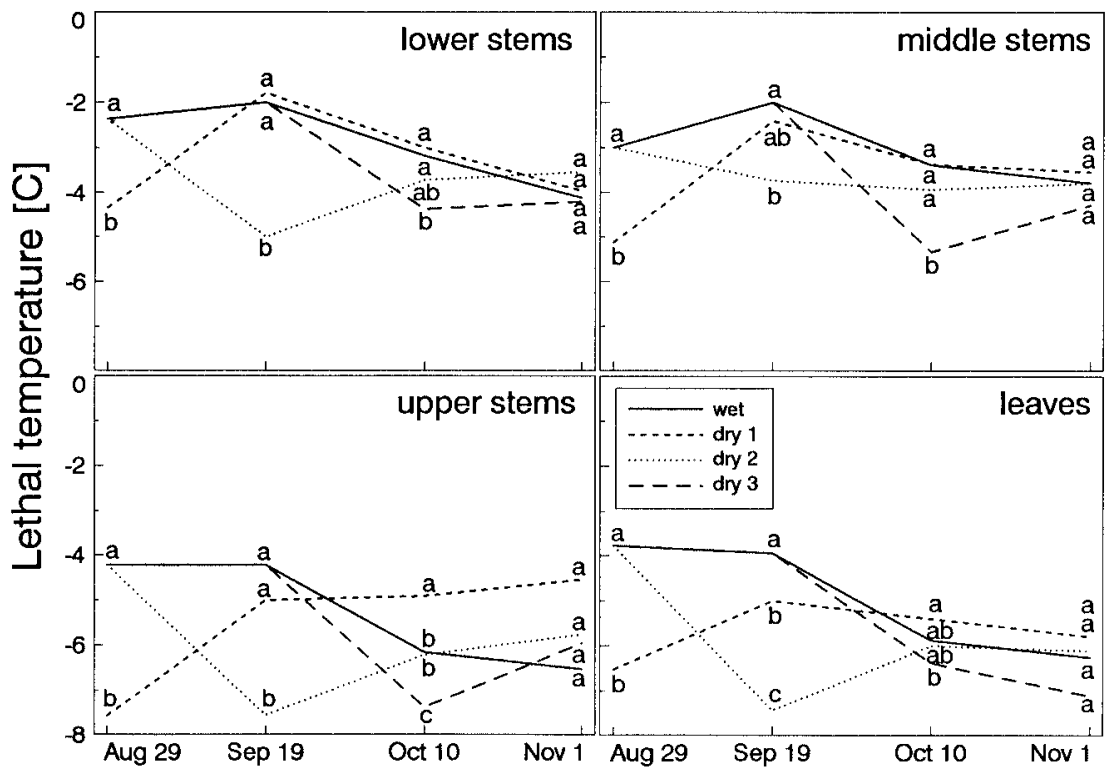

Fig. 4. The lethal temperature for lower, middle, and upper stems, and leaves of Rhododendron 'Red Ruffle' plants subjected to four watering regimes (mean separation between the watering regimes within a freeze test date by Tukey's studentized range; data points with the same letters do not differ significantly at $P=0.05$ ).

between 30 Aug. and 10 Oct. (Anisko and Lindstrom, 1995).

Three weeks after completing the water stress treatments, the cold hardiness of water stressed plants was the same as in the control plants, except for HD plants under the dry 3 treatment. On 1 Nov., HD plants exposed to the dry 3 treatment continued to be 1.0C (middle stems) to $4.3 \mathrm{C}$ (upper stems) more cold hardy than plants in the wet treatment. Some plant parts of HD plants exposed to the dry 1 (middle stems) and dry 2 (leaves) treatments remained more cold hardy than those under the wet treatment when tested three weeks after rewatering. In most cases, however, water stressinduced increase of cold hardiness diminished to a negligible value of about $1 \mathrm{C}$ or less 3 weeks after rewatering.

These findings are supported by earlier observations (Anisko and Lindstrom, 1995) where water stress-induced cold hardiness of greenhouse grown RR plants disappeared 6 weeks after normal watering was resumed. The decrease in cold hardiness after rewatering of previously water stressed plants also agrees with the findings of Parsons and Li (1979) for red-osier dogwood and Amundson et al. (1993) for red spruce. Timmis and Tanaka (1976), however, observed that Douglas-fir seedlings grown under dry conditions later had the ability to harden more than seedlings provided with adequate water. The Timmis and Tanaka (1976) study differed from our study in the temperature regime maintained during the recovery from water stress. Timmis and Tanaka (1976) exposed plants to $2 \mathrm{C}$ for a number of weeks after rewatering. In our study, plants were exposed to mean temperatures, ranging for each 3 -week period after rewatering, from 17 to $25 \mathrm{C}$, and daily mean temperature was never below 12C (Fig. 1C). Parsons and Li (1979), who observed similar results to ours, placed their plants under a 20C/15C (day/night) regime.

Daylength could also affect the plant's ability to retain water stress-induced cold hardiness. Parsons and Li (1979) reported that the cold hardiness of water stressed red-osier dogwood plants under 8 - and 16-h photoperiod decreased by $5 \mathrm{C}$ and $10 \mathrm{C}$, respec- 


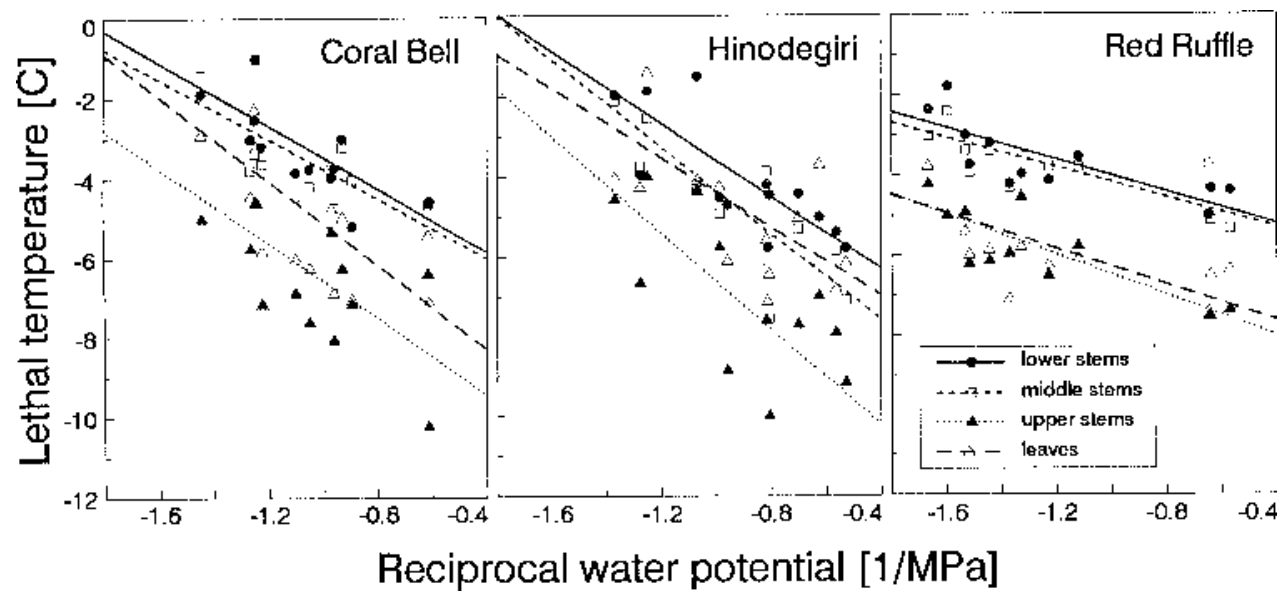

tively, 3 weeks after rewatering. Timmis and Tanaka (1976) maintained an 8-h photoperiod during recovery from water stress, while in our study the natural daylength was between 13.5 to 10.5 hours (8 Aug. to 1 Nov.). In our study, high temperatures and long photoperiod may have prevented the retention of water stressinduced cold hardiness after rewatering.

Throughout the experiment, lower stems were consistently less cold hardy than upper stems under all watering regimes (Figs. 24). The difference ranged for $\mathrm{CB}$ from $1.4 \mathrm{C}$ (dry 1 on 1 Nov.) to 5.7C (dry 3 on 10 Oct.), for HD from $1.3 \mathrm{C}$ (dry 1 on 10 Oct.) to $6.3 \mathrm{C}$ (dry 3 on 1 Nov.), and for RR from 0.6C (dry 1 on 1 Nov.) to 3.2C (dry 1 on 29 Aug.). Alexander and Havis (1980) found that the induction of freeze tolerance in evergreen azaleas proceeds in phases. During the early stages of cold acclimation, the apices are the most cold hardy followed in order by the upper stem area and the lower stem area. The difference in cold hardiness between lower and upper stems in our study was not affected by the employed watering regimes.

Cold hardiness of all cultivars in our study strongly depended on the current water status of the plants, as indicated by stem water potential (Fig. 5). The relationship between current water status and cold hardiness confirms that an increase in cold hardiness, induced by water stress, was transient and lost when water potential returned to control values. It may also allow to estimate cold hardiness during early stages of acclimation based on the current plant water potential. The coefficient of determination for the regression of lethal temperature vs. the reciprocal water potential ranged in CB from 0.48 (middle stems) to 0.60 (lower stems), in HD from 0.45 (leaves) to 0.78 (middle stems), and in RR from 0.64 (leaves) to 0.79 (upper stems). Regression analysis revealed that the increase in cold hardiness of RR was less responsive to water stress than that of $\mathrm{CB}$ and HD. While the slope of the linear relationship between lethal temperature and reciprocal water potential ranged in RR from -1.86 (middle stems) to -2.54 (upper stems), it ranged in CB from -3.74 (middle stems) to -5.29 (leaves), and in HD from -4.30 (leaves) to -6.01 (upper stems).

This study demonstrated that a 3-week period of reduced water supply was sufficient to lower water potential in evergreen azaleas and increase their cold hardiness from 1 to $4 \mathrm{C}$ in late summer and early fall. The effect was independent of the timing of the reduced watering. Water stress-induced cold hardiness was lost 3 weeks after normal watering resumed. The relationship between lethal temperature and water potential observed in this study may be used to determine the water stress necessary to induce desired levels of cold hardiness in evergreen azaleas during early stages of acclimation.
Fig. 5. Relationship between the reciprocal of stem water potential and the lethal temperature for lower, middle, and upper stems, and leaves of Rhododendron 'Coral Bell' (lower stems: $\mathrm{y}=-7.43-3.96 \times, R^{2}$ $=0.60$; middle stems: $\mathrm{y}=-7.50-3.74 \times$, $R^{2}=0.48$; upper stems: $\mathrm{y}=-11.33-$ $4.75 \times, R^{2}=0.49$; leaves: $\mathrm{y}=-10.41-$ $\left.5.29 \times, R^{2}=0.50\right), R$. 'Hinodegiri' (lower stems: $\mathrm{y}=-8.10-4.51 \times, R^{2}=0.71$; middle stems: $\mathrm{y}=-9.73-5.39 \times, R^{2}=$ 0.78 ; upper stems: $\mathrm{y}=-12.63-6.01 \times, R^{2}$ $=0.52$; leaves: $\mathrm{y}=-8.69-4.30 \times, R^{2}=$ 0.45 ), and $R$. 'Red Ruffle' (lower stems: $\mathrm{y}=-6.00-1.99 \times, R^{2}=0.74 ;$ middle stems: $\mathrm{y}=-6.04-1.86 \times, R^{2}=0.76$; upper stems: $\mathrm{y}=-9.03-2.54 \times, R^{2}=0.79$; leaves: $\left.\mathrm{y}=-8.55-2.26 \times, R^{2}=0.64\right)$.
Alexander, L.A. and J.R. Havis. 1980. Cold acclimation of plant parts in an evergreen and deciduous azalea. HortScience 15:89-90.

Amundson, R.G., R.J. Kohut, J.A. Laurence, S. Fellows, and L.J. Colavito. 1993. Moderate water stress alters carbohydrate content and cold tolerance of red spruce foliage. Environ. Expt. Bot. 33:383-390.

Anisko, T. and O.M. Lindstrom. 1995. Reduced water supply induces fall acclimation of evergreen azaleas. J. Amer. Soc. Hort. Sci. 120:429-434.

Anisko, T., D.S. NeSmith, and O.M. Lindstrom. 1994. Time-domain reflectometry for measuring water content of organic growing media in containers. HortScience 29:1511-1513.

Blake, J., J. Zaerr, and S. Hee. 1979. Controlled moisture stress to improve cold hardiness and morphology of Douglas-fir seedlings. For. Sci. 25:576-582.

Burrows, R.L., L. Waters, Jr., and A.H. Markhart, III. 1989. Cold acclimation of asparagus seedlings subjected to low temperatures or water stress. HortScience 24:812-814.

Calme, S., H.A. Margolis, and F.J. Bigras. 1993. Influence of cultural practices on the relationship between frost tolerance and water content of containerized black spruce, white spruce, and jack pine seedlings. Can. J. For. Res. 23:503-511.

Chen, H.H. and P.H. Li. 1978. Interactions of low temperature, water stress, and short days in the induction of stem frost hardiness in red-osier dogwood. Plant Physiol. 62:833-835.

Chen, P.M., P.H. Li, and C.J. Weiser. 1975. Induction of frost hardiness in red-osier dogwood stems by water stress. HortScience 10:372-374. Chen, P.M., P.H. Li, and M.J. Burke. 1977. Induction of frost hardiness in stem cortical tissues of Cornus stolonifera Michx. by water stress. I. Unfrozen water in cortical tissues and water status in plants and soil. Plant Physiol. 59:236-239.

Cloutier, Y. and D. Siminovitch. 1982. Correlation between cold- and drought-induced frost hardiness in winter wheat and rye varieties. Plant Physiol. 69:256-258.

Colombo, S.J. 1990. Bud dormancy status, frost hardiness, shoot moisture content, and readiness of black spruce container seedlings for frozen storage. J. Amer. Soc. Hort. Sci. 115:302-307.

Cox, W. and J. Levitt. 1976. Interrelations between environmental factors and freezing resistance of cabbage leaves. Plant Physiol. 57:553-555.

Gusta, L.V., D.B. Fowler, and N.J. Tyler. 1982. Factors influencing hardening and survival in winter wheat, p. 23-40. In: P.H. Li and A. Sakai (eds.). Cold hardiness and freezing stress. vol. 2. Mechanisms and crop implications.

Jonsson, A., G. Eriksson, I. Dormling, and J. Ifver. 1981. Studies on frost hardiness of Pinus contorta Douglas seedlings grown in climate chambers. Study For. Suecica 157:1-47.

Li, P.H. and C.J. Weiser. 1971. Increasing cold resistance of stem sections of Cornus stolonifera by artificial dehydration. Cryobiology 8:108-111. Lindstrom, O.M., P.H. Li, and H.M. Pellett. 1977. Flower bud hardiness of Rhododendron $\times$ kosterianum. Quarterly Bul. Amer. Rhododendron 
Soc. 31:223-225.

McKenzie, J.S., C.J. Weiser, and P.H. Li. 1974. Changes in water relations of Cornus stolonifera during cold acclimation. J. Amer. Soc. Hort. Sci. 99:223-228.

Nelson, J.M., D.A. Palzkill, and P.G. Bartels. 1993. Irrigation cut-off date affects growth, frost damage, and yield of jojoba. J. Amer. Soc. Hort. Sci. 118:731-735.

Paquin, R. 1977. Influence of soil moisture content on frost resistance of alfalfa (Medicago media Pers.). Plant Physiol. 59:S-36.

Parsons, L.R. 1978. Water relations, stomatal behavior, and root conductivity of red osier dogwood during acclimation to freezing temperatures. Plant Physiol. 62:64-70.

Parsons, L.R. and P.H. Li. 1979. Changes in frost hardiness of stem cortical tissues of Cornus stolonifera Michx. after recovery from water stress. Plant Physiol. 64:351-353.

Pellett, N.E. and D.B. White. 1969. Relationship of seasonal tissue changes to cold acclimation of Juniperus chinensis 'Hetzi'. J. Amer. Soc. Hort. Sci. 94:460-462.

Siminovitch, D. 1977. Induction of cold hardiness and plasmolysis injury resistance in coleoptiles and epicotyls of winter rye seedlings in the dark at room temperature by desiccation. Plant Physiol. 59:S-4.

Stout, D.G. 1980. Alfalfa water status and cold hardiness as influenced by cold acclimation and water status. Plant Cell Environ. 3:237-241.

Takatoi, I., T. Watanabe, and U. Kamado. 1964. The frost hardiness of birch and alder trees in the autumn, their water contents, refractive indices, and the concentration of their cortical cell saps. Frost damage on forest trees (V). Annu. Rpt., Hokkaido Branch For. Expt. Sta., Sapporo, Japan.

Timmis, R. and Y. Tanaka. 1976. Effects of container density and plant water stress on growth and cold hardiness of Douglas-fir seedlings. For. Sci. 22:167-172.

Tyler, N.J., L.V. Gusta, and D.B. Fowler. 1981. The effect of a water stress on the cold hardiness of winter wheat. Can. J. Bot. 59:1717-1721.

van den Driessche, R. 1969. Influence of moisture supply, temperature, and light on frost-hardiness changes in Douglas-fir seedlings. Can. J. Bot. 47:1765-1772.

Yelenosky, G. 1979. Water stress-induced cold hardening of young citrus trees. J. Amer. Soc. Hort. Sci. 104:270-273. 